\title{
Greater Arch Injuries
}

\author{
Deepak Shivanna • Dayanand Manjunath • \\ Rajkumar Amaravathi
}

Received: 6 January 2014 / Accepted: 13 June 2014 / Published online: 22 June 2014

(C) Society of the Hand \& Microsurgeons of India 2014

\begin{abstract}
Dislocations and fracture dislocations of carpal bones are uncommon injuries which invariably poses challenges in the management. Perilunate fracture dislocations are the combination of ligamentous and osseous injury that involve the "greater arc" of the perilunate associated instability. Despite their severity, these injuries often go unrecognized in the emergency department leading to delayed diagnosis and treatment. A Prospective study was done from June 2008 to December 2013 in 15 cases of complex wrist injuries which included of greater arch injuries, perilunate fracture dislocation and one dorsal dislocation of Scaphoid. 10 cases of perilunate fracture dislocation underwent open reduction and internal fixation with Herbert screw and k-wire, 4 cases of greater arch injury underwent closed reduction and kwire fixation and one case of neglected dorsal dislocation underwent proximal row carpectomy. One patient had Sudecks osteodystrophy 1 had Scaphoid nonunion and 6 had median nerve compression. Overall outcome according to Mayo wrist score was $53 \%$ excellent, $33 \%$ good and $14 \%$ fair. Greater arch injuries are difficult to treat because injuries to many ligaments are involved and failure to recognize early leads to persistent pain, disability and early onset of arthritis. Prompt recognition requires CT scan and MRI. Management requires reduction and multiple $\mathrm{K}$-Wiring according to merits of the case.
\end{abstract}

D. Shivanna $\cdot$ D. Manjunath $(\bowtie)$

Bangalore Medical College and Research Institute, 304, Elegant

West Wood Apartments, 11th Cross,11th Main, Malleswaram,

Bangalore, Karnataka, India

e-mail: drdayanand.m@gmail.com

R. Amaravathi

Stjohns Medical College And Hospital, Sarjapur Road, Bangalore, Karnataka, India
Keywords Greater arc injury · Perilunate fracture dislocation · Carpal tunnel syndrome

\section{Introduction}

Dislocations and fracture dislocations of carpal bones are uncommon injuries which invariably poses challenges in the management. Early diagnosis and appropriate treatment of these carpal disruptions are necessary to prevent progressive carpal instability and traumatic arthritis. Despite their severity, these injuries often go unrecognized leading to delayed diagnosis and treatment. It was Malgaigne in 1855, who first described perilunate fracture dislocation [1]. Greater arc injuries are Perilunate carpal fractures with potential ligamentous damage. Lesser arc injuries are pure ligamentous disruptions without fracture. Collectively greater arc and lesser arc regions are called as vulnerable zones where vast majority of carpal fractures and dislocations occur [2]. Fracture dislocations of wrist range from a displaced radial styloid and transscaphoid fractures to complex trans-carpal injuries. These injuries result from excessive stress to the dorsiflexed wrist with significant dorsal compression and anterior tension force most commonly seen in high velocity injuries.

It is hypothesized that most perilunate fracture dislocations result from high energy three dimensional loading of the wrist where axial or torsion forces are applied with the wrist in any combination of hyper-extension, hyper-flexion and radial or ulnar deviation [1]. Final lesion is determined by type of loading with respect to the wrist at impact, the magnitude and direction of the forces involved and individual biomechanical properties of the bone and ligaments [1]. With paucity of clinical signs, proper investigations help in the diagnosis. A standard PA view and a lateral view of the wrist, traction radiographs and tomograms also aids in the diagnosis [1]. Lateral radiograph is the key, with the finding being loss of 
co linearity of the radius, lunate and capitate. In dorsal perilunate dislocation, capitate rests dorsal to the lunate. In volar perilunate dislocation, the lunate pivots around the intact radio-lunate ligament and faces anteriorly, a finding termed as "spilled cup sign". Capitate migrates proximally into the lunate fossa. On the PA view overlap of carpal bones and loss of carpal height are evident [4]. There are five major stages of carpal dislocation and four fracture dislocations and the primary effort of treatment is directed to the anatomic reduction of greater arc injuries with repair of associated ligament injury 1 . According to the current literature, at medium-term followup, radiological signs of arthritis do not correlate with functional scores. The aim of this study was to evaluate hand function after greater arc injuries (Table 1).

\section{Materials and Method}

A Prospective study was done from June 2008 to December 2013 in 15 cases of complex wrist injuries which included greater arch injuries, perilunate fracture dislocation and one dorsal dislocation of scaphoid. All were investigated with radiograph, CT scan and MRI. Nerve conduction studies were done to rule out Median nerve compression. They were operated with closed/open reduction and internal fixation and proximal row carpectomy in one case. All Perilunate fracture dislocations were treated by open reduction and internal fixation.

Open reduction was done through dorsal approach in all cases and a combined volar and dorsal approach was used for proximal row carpectomy with median nerve compression.

Greater arch injuries which included fracture of radial styloid, Scaphoid and capitate without dislocation were treated by closed reduction and internal fixation.. Carpal tunnel decompression was done via volar approach in required cases. Physiotherapy was done after removal of $\mathrm{K}$ wire, with passive ROM movements for 2 weeks and then active ROM. Wax bath was given for patients with persistent stiffness. Patients were followed for 1 year and outcome assessed using Mayo wrist score (Figs. 1, 2, 3, 4, 5 and 6).

\section{Results}

The average age of the patients was 32 years (range 2440 years) and average median duration of injury to surgery was 7 days (range 1-75 days). Of the 15 wrists injuries, 4 were greater arc injuries, 10 were perilunate fracture dislocation and one neglected dorsal dislocation. 9 cases were RTA, 5 cases were due to fall from height and 1 was due to fall of a heavy object. One of our case was bilateral and 9 cases were right wrist and 4 cases were left. All the patients in our series were

Table 1 Details of cases

\begin{tabular}{|c|c|c|c|c|c|c|}
\hline no & $\begin{array}{l}\text { Mode of } \\
\text { injury }\end{array}$ & Diagnosis & $\begin{array}{l}\text { Time of } \\
\text { surgery }\end{array}$ & Procedure & Complications & Outcome \\
\hline 1 & RTA & Greater arch injury & Same day & $\begin{array}{l}\text { CR and Herbert screw for Scaphoid } \\
\text { and kwire }\end{array}$ & none & Excellent \\
\hline 2 & RTA & $\begin{array}{l}\text { Transscaphoid Perilunate fracture } \\
\text { dislocation }\end{array}$ & 1 week & $\begin{array}{l}\text { OR and Herbert screw and kwire } \\
\text { and carpal tunnel release }\end{array}$ & Median nerve compression & Good \\
\hline 3 & Fall from ht & $\begin{array}{l}\text { Transscaphoid Perilunate fracture } \\
\text { dislocation }\end{array}$ & 1 week & $\begin{array}{l}\text { OR \& Herbert screw \& kwire \& } \\
\text { carpal tunnel release }\end{array}$ & Median nerve compression & Good \\
\hline 4 & RTA & Greater arch injury & Same day & $\begin{array}{l}\text { CR \& kwire and Herbert screw for } \\
\text { Scaphoid }\end{array}$ & none & Excellent \\
\hline 5 & RTA & Perilunate fracture dislocation & 1 week & $\begin{array}{l}\text { OR \& kwire and carpal tunnel } \\
\text { release }\end{array}$ & Medial nerve compression & Excellent \\
\hline 6 & RTA & $\begin{array}{l}\text { Transscaphoid Perilunate fracture } \\
\text { dislocation }\end{array}$ & 1 week & $\begin{array}{l}\text { OR and Herbert screw and kwire } \\
\text { and carpal tunnel release }\end{array}$ & $\begin{array}{l}\text { Median } \\
\text { nerve compression }\end{array}$ & Good \\
\hline 7 & RTA & Greater arch injury & Same day & $\begin{array}{l}\text { CR \& kwire and Herbert screw for } \\
\text { Scaphoid }\end{array}$ & none & Excellent \\
\hline 8 & Fall from ht & $\begin{array}{l}\text { Transscaphoid Perilunate fracture } \\
\text { dislocation }\end{array}$ & 1 week & $\begin{array}{l}\mathrm{OR} \text { and Herbert screw and kwire } \\
\text { and carpal tunnel release }\end{array}$ & Median nerve compression & Good \\
\hline 9 & RTA & Greater arch injury [5] & Same day & CR \& kwire and kwire & none & Excellent \\
\hline 10 & $\begin{array}{l}\text { Fall of heavy } \\
\text { weight }\end{array}$ & $\begin{array}{l}\text { Neglected dorsal dislocation of } \\
\text { scaphoid [6] }\end{array}$ & 4 months & $\begin{array}{l}\text { Proximal row carpectomy and } \\
\text { carpal }\end{array}$ & & Fair \\
\hline 11 & Fall from ht & Perilunate fracture dislocation & 1 week & $\begin{array}{l}\text { OR \& Kwire \& carpal tunnel } \\
\text { release }\end{array}$ & $\begin{array}{l}\text { Median nerve compression, } \\
\text { Scaphoid nonunion }\end{array}$ & Good \\
\hline 12 & RTA & $\begin{array}{l}\text { Trans Scaphoid perilunate fracture } \\
\text { dislocation }\end{array}$ & same & OR and Herbert screw and kwire & none & Excellent \\
\hline 13 & Fall from ht & $\begin{array}{l}\text { Trans Scaphoid perilunate fracture } \\
\text { dislocation bilateral }\end{array}$ & same & $\begin{array}{l}\text { OR and Herbert screw and kwire on } \\
\text { both sides }\end{array}$ & none & $\begin{array}{r}\text { Excellent on } \\
\text { both sides }\end{array}$ \\
\hline 14 & Fall from ht & Perilunate fracture dislocation & same & OR and kwiring & Sudeck's osteodystrophy & Fair \\
\hline
\end{tabular}



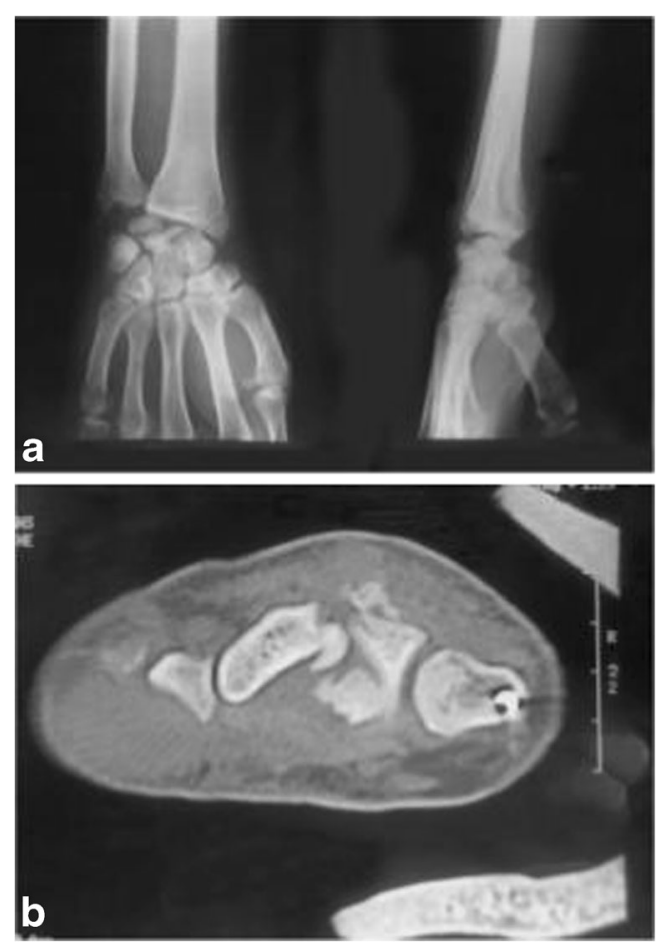

Fig. 1 a Postero-anterior and lateral radiograph of right wrist showing fractures of the radial and ulnar styloid process, proximal pole fracture of scaphoid, chip fracture of the capitate, comminuted fracture of the triquetrum and saggital fracture of the body of lunate $\mathbf{b}$ Computerised tomogram showing saggital fracture of lunate and chip fracture of capitates

right hand dominant. 6 cases presented 1 week after the injury and one case presented 2.5 months later. 4 cases of greater arc injury underwent closed reduction and internal fixation with $\mathrm{K}$-wire, 10 cases of Perilunate fracture dislocation underwent open reduction and internal fixation of Scaphoid fracture with Herbert screw and K-wire fixation. One case of neglected dorsal dislocation underwent proximal row carpectomy. 6 cases had median nerve compression for which they underwent carpal tunnel decompression via volar approach and recovered fully. One case had Sudecks osteodystropy and one had non union of Scaphoid who underwent bone grafting and K-wire fixation which healed after 4 months. Overall

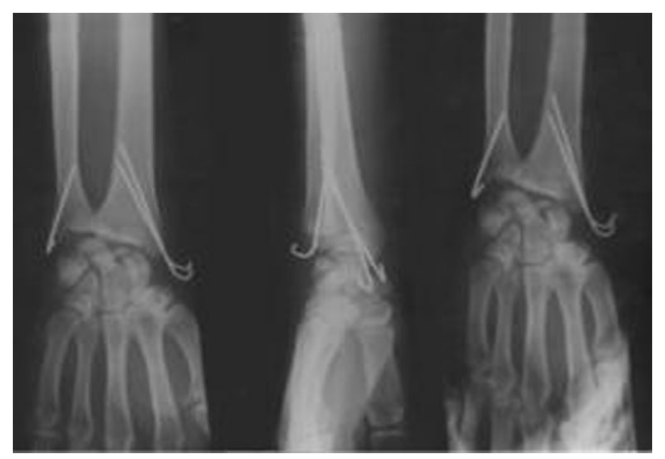

Fig. 2 Postero-anterior, lateral and oblique radiograph of right wrist showing K-wire fixation of radial and ulnar styloid

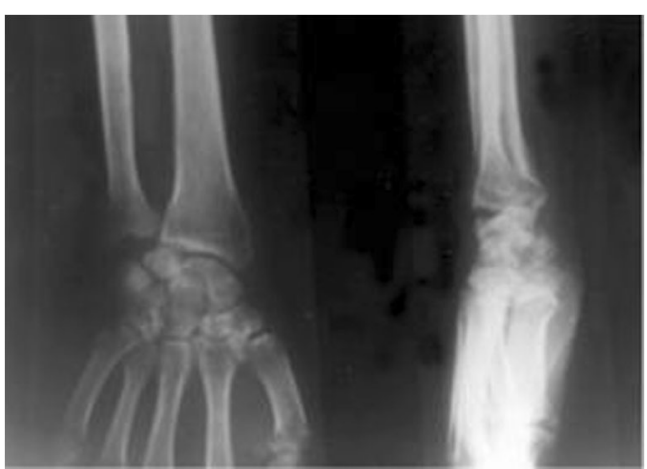

Fig. 3 Latest follow up of the right wrist showing good union of most fractures in the postero-anterior and lateral radiograph

outcome according to Mayo wrist score was $53 \%$ excellent, $33 \%$ good and $14 \%$ fair.

\section{Discussion}

There is a striking paradox between the significance of the trauma to the wrist and the paucity of clinical signs to support these serious injuries. However on examination of the wrist, tenderness is not isolated to a single area and significant dorsal or palmar pain on palpation are pathognomic of perilunate fracture dislocation [1]. The presenting symptoms in delayed cases are severe in-capacitating wrist pain, persistent swelling of the wrist with inability to flex the fingers and paraesthesia in the hand. In late presentation of perilunate fracture dislocations, the symptoms were of carpal tunnel syndrome or attrition rupture of flexor tendons [1]. Perilunate fracture dislocation represents only $5 \%$ of fractures about the wrist [3]. They are twice as frequent as the pure ligamentous perilunate dislocations. Vast majority are closed injuries. Open cases are less than $10 \%$. At initial presentation, these are quite complex injuries that often lack an accurate diagnosis. A recent multicentric review of these injuries showed that the diagnosis was missed initially in $25 \%$ of the cases [1]. They occur from sports related or work related falls, from falls, from motor vehicle accidents or miscellaneous high energy trauma [1].

In our series mean average age of the patient was 32 years as compared to the mean average age of the patients was 38 years study done by Sotereanos DG et al [7]. In our study the average duration of injury to surgery was 7 days, Herzberg $\mathrm{G}$ et all [8] reported a series of 14 trans-scaphoid dorsal perilunate fracture-dislocations treated operatively at an average of 6 days following injury. The treatment of perilunate fracture dislocation depends on the degree of initial trauma, associated soft tissue injury and delay in evaluation. However if anatomical reduction is achieved by closed reduction, percutaneous K-wire fixation is a good option. Open reduction is reserved for trans-radial styloid fracture dislocations, transcaphoid or transcapitate fracture dislocations or in cases 
Fig. 4 Trans Scaphoid perilunate fracture dislocation.।

Fig. 5 Postop radiograph

Fig. 6 Followup
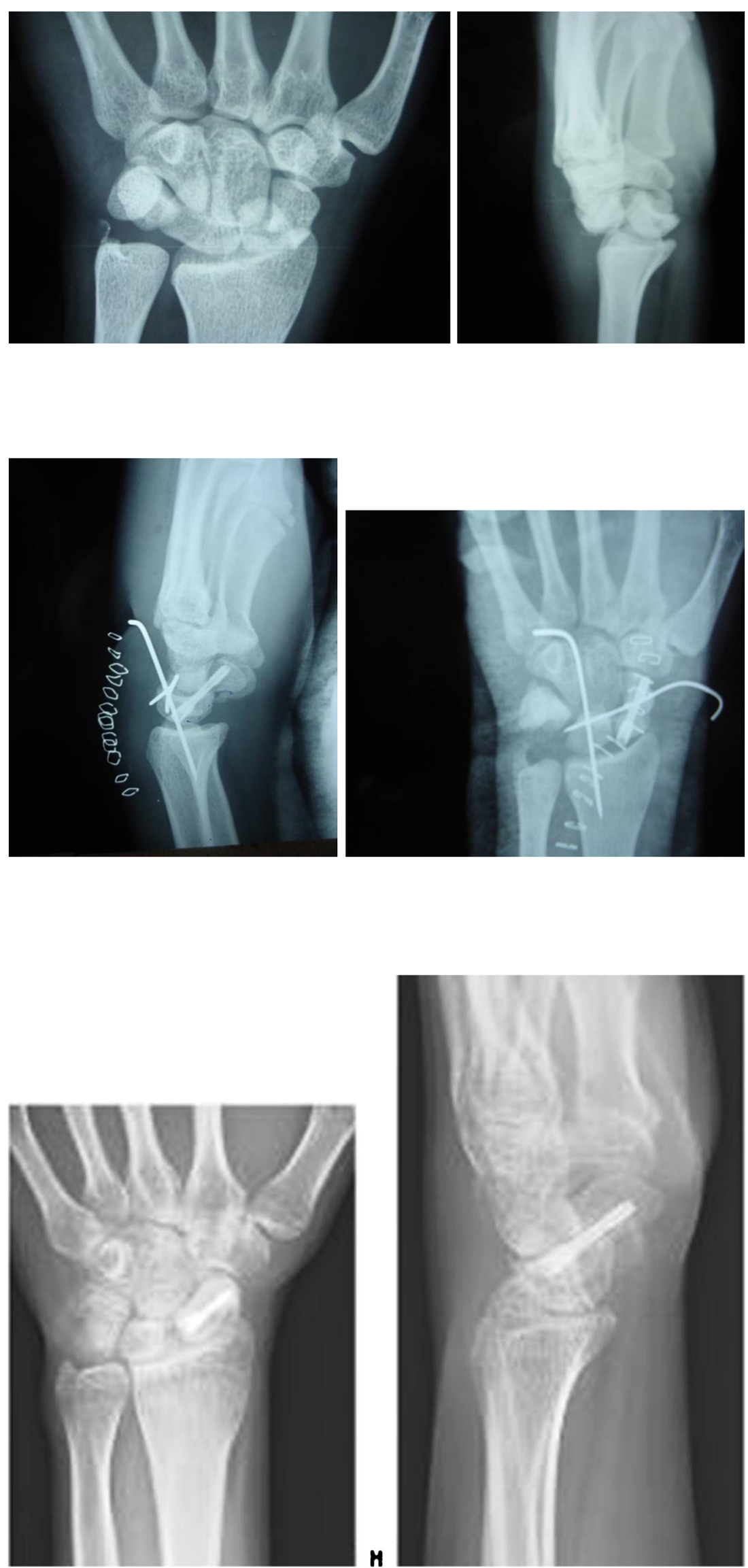

H

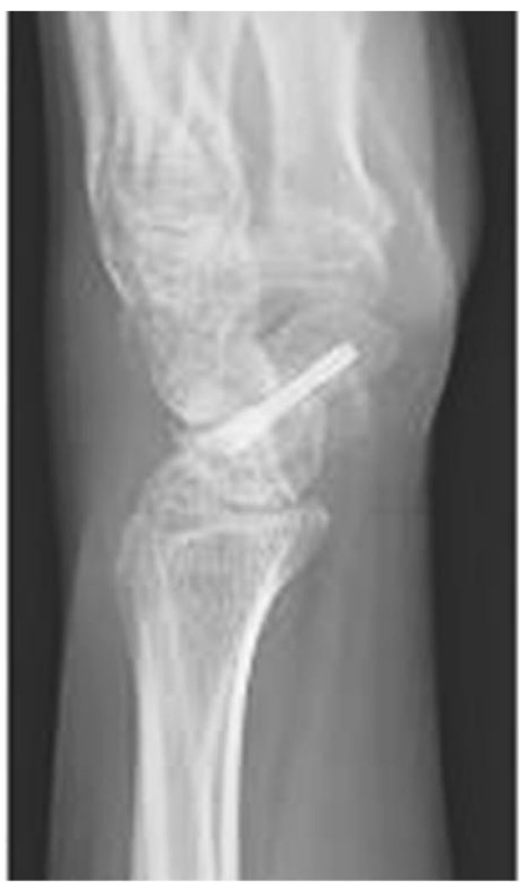


of total palmar dislocations of the lunate. Post operatively a long arm thumb spica is applied for at least 8 to 12 weeks and till the fracture scaphoid shows union [1]. In our study 6 cases had median nerve compression and one case had Sudecks osteodystropy as compared to 4 cases of median nerve injury and one case of Sudecks osteodystrophy in a study conducted by Herzberg $\mathrm{G}$ et all [8]. In our series overall outcome according to Mayo wrist score was $53 \%$ excellent, $33 \%$ good and $14 \%$ fair which is similar to the study of Herzberg G et all [8] which reported five excellent, three good, five fair and one poor result.

True complications are due to inadequate treatment of ligament injuries leading to carpal instability and arthrosis. In such cases salvage operation like proximal row carpectomy is preferred [1]. Although the successful results have been reported as late as 4 to 5 months after the injury, best results are seen when definitive treatment is performed within 1 to 2 weeks. Most patients will gain approximately $50 \%$ of the normal motion and some stiffness is the rule [4].

The current trend of the treatment is towards early open reduction and direct repair of injured structures as closed management in such high energy injury is frequently unsuccessful and unreliable ${ }^{2}$.

\section{Conclusion}

Greater arch injuries are difficult to treat because of the complex anatomy and are frequently missed, failure to recognize leads to persistent pain, disability and early onset of arthritis.

Prompt recognition requires CT and MRI. Management requires reduction and multiple $\mathrm{K}$-Wiring according to merits of the case. Median nerve compression in carpal tunnel is commonly seen which requires decompression and recovers if done in time. Cases presenting late with arthritis usually require radical procedures like proximal row carpectomy to provide pain free and mobile wrist.

\section{References}

1. Herzberg G, Cooney WP (1998) Perilunate fracture dislocations. In: Cooney WP, Linscheid RL, Dobyns JH (eds) The wrist :diagnosis and operative treatment, vol I. Mosby, Philadelphia, pp 651-83

2. Kozin SH, Murphy MS, Cooney WP (1998) Perilunate dislocations. In: Cooney WP, Linscheid RL, Dobyns JH (eds) The wrist :diagnosis and operative treatment, vol I. Mosby, Philadelphia, pp 632-50

3. Cooney WP, Bussey R, Dobyns JH, Linscheid RL (1987) Difficult wrist fracture. Perilunate fracture dislocation of wrist. Clin Orthop 214: $136-47$

4. Ruby LK, Casidy C (2003) Fractures and dislocations of the carpus. In: Browner BD Jupiter JB, Levine AM, Trafton PG (eds) Skeletal trauma: basic science management and reconstruction. Vol II, vol 3rd. WB Saunders, Philadelphia, pp 1261-313

5. Amaravati RS, Saji MJ, Rajagopal HP (2005) Greater arc injury of the wrist with fractured lunate bone: a case report. J Orthop Surg 13(3): 310-313

6. Amaravati RS, Saji MJ, Rajagopal HP, Gururaj (2009) Neglected dorsal dislocation of the Scaphoid. Indian J Orthop 43(2):213-5

7. Sotereanos DG, Mitsionis GJ, Giannakopoulos PN, Tomaino MM, Herndon JH (1997 Jan) Perilunate dislocation and fracture dislocation: a critical analysis of the volar-dorsal approach. J Hand Surg [Am] 22(1):49-56

8. Herzberg G, Forissier D (2002 Dec) Acute dorsal trans-scaphoid perilunate fracture-dislocations: medium-term results. J Hand Surg (Br) 27(6):498-502 